\title{
Effects of an additional small group discussion to cognitive achievement and retention in basic principles of bioethics teaching methods
}

\author{
Dedi Afandi ${ }^{1}$, Yuli Budiningsih², Oktavinda Safitry ${ }^{2}$, Agus Purwadianto ${ }^{2}$, Dwi Novitasari ${ }^{3}$, Ivan Riyanto Widjaja ${ }^{4}$ \\ 1 Department of Forensic Medicine and Medico legal, Faculty of Medicine, University of Riau, Pekanbaru, Indonesia \\ 2 Department of Forensic Medicine and Medico legal, Faculty of Medicine, University of Indonesia, Jakarta, Indonesia \\ 3 Department of Health Republic of Indonesia, Jakarta, Indonesia \\ 4 Sixth year medical student, Faculty of Medicine, University of Indonesia, Jakarta, Indonesia
}

\begin{abstract}
Abstrak
Tujuan Kedudukan etik dalam kurikulum fakultas kedokteran adalah sangat esensial tetapi metode pengajaran etika kedokteran tidak begitu banyak berubah. Kaidah dasar bioetika merupakan pengetahuan yang relevan untuk membangun pemikiran kritis mahasiswa tentang etika kedokteran. Penelitian ini bertujuan untuk meneliti efek pengaruh penambahan diskusi kelompok kecil pada metode kuliah konvensional terhadap tingkat pengetahuan dan retensi dari materi kaidah dasar bioetika. Penelitian ini merupakan uji kasus-kontrol, acak, dengan desain paralel. Tes Kaidah Dasar Bioetika digunakan untuk mengukur tingkat kognitif dan retensi dari pengetahuan kaidah dasar bioetika. Kelompok kontrol akan diberikan kuliah secara konvensional, sedangkan kelompok intervensi selain kuliah akan dilanjutkan dengan diskusi kelompok kecil.
\end{abstract}

Hasil Kuliah umum konvensional, dengan atau tanpa penambahan diskusi kelompok kecil dapat meningkatkan tingkat pengetahuan dan retensi tentang kaidah dasar bioetika (masing-masing $P=0.001$ and $P=0.000$ ). Terdapat perbedaan yang bermakna antara tingkat pengetahuan dan tingkat retensi antara kelompok kontrol dengan kelompok intervensi $(P=0.000, P=0.000$, masing-masing $)$.

Simpulan Metode pengajaran dengan tambahan diskusi kelompok kecil lebih baik daripada metode kuliah konvensional dalam meningkatkan pengetahuan dan retensi kaidah dasar bioetika. (Med J Indones 2009; 18: 48-52)

\begin{abstract}
Aim The place of ethics in undergraduate medical curricula is essential but the methods of teaching medical ethics did not show substantial changes. "Basic principles of bioethics" is the best knowledge to develop student's reasoning analysis in medical ethics In this study, we investigate the effects of an additional small group discussion in basic principles of bioethics conventional lecture methods to cognitive achievement and retention. This study was a randomized controlled trial with parallel design. Cognitive scores of the basic principles of bioethics as a parameter was measured using basic principles of bioethics (Kaidah Dasar Bioetika, KDB) test. Both groups were attending conventional lectures, then the intervention group got an additional small group discussion.

Result Conventional lectures with or without small group discussion significantly increased cognitive achievement of basic principles of bioethics $(\mathrm{P}=0.001$ and $\mathrm{P}=0.000$, respectively), and there were significant differences in cognitive achievement and retention between the 2 groups $(\mathrm{P}=0.000$ and $\mathrm{P}=0.000$, respectively).

Conclusion Additional small group discussion method improved cognitive achievement and retention of basic principles of bioethics. (Med J Indones 2009; 18: 48-52)
\end{abstract}

Keywords: lecture, specification checklist, multiple choice questions

Significant progress has been made in developing the place of ethics in undergraduate medical curriculum over the last two decades. ${ }^{1}$ Today the medical profession has become so complex that a systematic approach to medical ethics is essential ${ }^{2}$ That's why we need to prepare students for the challenges and struggles ahead. Medical ethics should be a core subject in the medical curriculum, and medical ethics curriculum development was the main necessity in medical ethics education. ${ }^{1-4}$

The "four basic principles of bioethics" is one of the medical ethics teaching material in many medical schools in the world. ${ }^{1,4-8}$ Application of the four principles - beneficence, non-maleficence, respect for 
autonomy, and justice - to solve an ethical problem is easier and more systematic for health professionals and students compared to other principles. ${ }^{5-10}$ A study in Jakarta showed that the basic principles of bioethics is the best tool to develop student's reasoning analysis in medical ethics with cognitive approach in medical school. ${ }^{11}$

Formal medical ethics education was originally classroom-based, and its pedagogic goals were cognitive. ${ }^{4}$ There were various teaching methods such as conventional lecture, seminars, workshops, discussions and even combinations them. ${ }^{2,6,9}$ Although the complexities of medical care have increased dramatically over the last century, the methods of teaching medical ethics did not show substantial changes. ${ }^{12}$ This study was designed to investigate the effects of an additional small group discussion in the "basic principles of bioethics" teaching method on cognitive achievement and retention.

\section{METHODS}

This study was a randomized controlled trial, with parallel design. The study was conducted from October 2007 to January 2008, at the Faculty of Medicine, University of Riau, Pekanbaru. The study population was pre-clinical medical students, academic year 20042007. Medical students who never get "basic principles of bioethics" material in the formal education were included. The participants were selected by multistage random sampling, and the sample size was calculated based on probability proportionate to size (PPS) sampling method for the independent t-test analysis on the effects of teaching methods (cognitive scores of "basic principles of bioethics"). Using a standard deviation of 2.14 from preliminary study results and significance level of 0.05 with at least $80 \%$ power to detect a minimum mean significant difference of 1.5 between the conventional lecture only (control) and an additional small group discussion (intervention) groups, 32 participants per group were required to complete the trial. Thus, a total of 70 participants were recruited and randomized to accommodate a drop-out rate of about $10 \%$. Multistage random sampling and randomization was done based on random number generated by Microsoft office excel ${ }^{\mathbb{}} 2003$.

\section{Procedure}

Both groups were attending one hour of conventional lecture held by the Department of Forensic Medicine and Medico Legal, Faculty of Medicine, University of Riau. The intervention group then was involved in an additional small group discussion, which method was adopted from "basic principles of bioethics" teaching methods at the Faculty of Medicine, University of Indonesia (FMUI). ${ }^{13}$ The small group discussion used trigger cases and specification checklists for each basic principle of bioethics, and time allocated was about half an hour for each of the principles.

\section{Data collection}

General data obtained from the participants were level of academic year and sex. The cognitive level of the "basic principles of bioethics" was measured using "basic principles of bioethics" (Kaidah Dasar Bioetika / KDB) test with an internal consistency reliability (KR 20 ) of 0.701 . This test consists of eight multiple choice questions, each with five options. Every right answer will be scored one and wrong answer zero. The maximum total score was 8 and cognitive level was considered adequate if the total score was 5 or higher. ${ }^{14}$ The level of cognitive achievement was evaluated immediately after the trial (Post-Test). Level of cognitive retention was evaluated three months after the trial (RetentionTest). All participants signed a written informed consent before participating in this study.

\section{Data Analysis}

SPSS $^{\circledR}$ for Windows version 14 (SPSS Inc, Chicago, Illinois) was used for inputting, processing, and analyzing the data obtained in the study. To determine the effect of teaching methods on cognitive achievement in "basic principles of bioethics" for each group, we used Wilcoxon signed ranks test and risk ratio (RR), whereas to determine the effect of the additional small group discussion on cognitive achievement and retention of "basic principles of bioethics", we analyzed the difference between the 2 groups using independent t-test or Mann Whitney U-test depending on the normality of the data distribution.

\section{RESULTS}

Seventy participants were enrolled in the study and completed the trial. They were randomized into control and intervention groups. The characteristics of participants are presented in Table 1. Most of participants in each group were female. 
The effect of teaching methods to cognitive achievement and cognitive retention of basic principles of bioethics for each group are presented in Table 2 . As presented, conventional lecture with or without additional small group discussion significantly increased cognitive achievement and retention. However, the additional small group discussion was more effective in increasing the level of both cognitive achievement and retention.
The difference between the 2 groups in cognitive achievement and retention of "basic principles of bioethic" are presented in Table 3. No significant difference $(P=0.333)$ of cognitive level was found before trial showing that both groups had the same bioethics knowledge when they started. Additional small group discussion showed a significantly greater cognitive achievement and retention than conventional lecture alone ( $P=0.000$ and $P=0.000$, respectively).

Table 1. Characteristics of participants $(n=70)$

\begin{tabular}{ccc}
\hline Characteristics & $\begin{array}{c}\text { Control Group } \\
\mathrm{n}=35\end{array}$ & $\begin{array}{c}\text { Intervention Group } \\
\mathrm{n}=35\end{array}$ \\
\hline Level of academic year & & \\
: $1^{\text {st }}$ year & 12 & 12 \\
- $2^{\text {nd }}$ year & 11 & 11 \\
- $3^{\text {rd }}$ year & 7 & 7 \\
Female, $(\%)$ & 5 & $\mathbf{5}$ \\
\hline
\end{tabular}

Table 2. Effect of teaching methods on cognitive achievement and retention

\begin{tabular}{|c|c|c|c|c|c|c|}
\hline & \multirow{2}{*}{\multicolumn{2}{|c|}{$\begin{array}{l}\text { Effect } \\
\mathrm{n}(\%)\end{array}$}} & \multicolumn{4}{|c|}{$95 \%$} \\
\hline & & & \multirow{2}{*}{$\begin{array}{c}\text { Crude } \\
\text { risk ratio }\end{array}$} & \multicolumn{2}{|c|}{ Confidence Interval } & \multirow{2}{*}{$p$ value } \\
\hline & positive rank (\%) & $\begin{array}{c}\text { negative-ties rank } \\
(\%)\end{array}$ & & Lower & Upper & \\
\hline Cognitive achievement ${ }^{\mathrm{a}}$ & & & 1.59 & 1.23 & 2.05 & \\
\hline - Intervention & $35(100)$ & $0(0)$ & & & & 0.000 \\
\hline - Control & $22(62.8)$ & $13(37.2)$ & & & & 0.001 \\
\hline Cognitive retention $^{b}$ & & & 1.63 & 1.18 & 2.26 & \\
\hline - Intervention & $31(88.6)$ & $4(11.4)$ & & & & 0.000 \\
\hline - Control & $19(54.3)$ & $16(47.3)$ & & & & 0.030 \\
\hline
\end{tabular}

${ }^{\text {a }}$ Difference between post-test and pre-test scores

${ }^{\mathrm{b}}$ Difference between retention-test and pre-test scores

${ }^{*}$ Wilcoxon signed ranks test

Table 3. Associations of teaching methods with cognitive achievement and retention

\begin{tabular}{lccc}
\hline \multicolumn{1}{c}{ Evaluation } & $\begin{array}{c}\text { Control Group } \\
\text { mean (SD) }\end{array}$ & $\begin{array}{c}\text { Intervention Group } \\
\text { mean (SD) }\end{array}$ & $\boldsymbol{p ~ v a l u e * ~}^{*}$ \\
\hline Pre-Test & $2.57(0.92)$ & $2.77(0.77)$ & 0.333 \\
Post-Test & $3.74(1.42)$ & $6.37(0.84)$ & 0.000 \\
Retention-Test & $3.31(1.47)$ & $5.54(1.65)$ & 0.000 \\
\hline
\end{tabular}

*Mann Whitney U-test 


\section{DISCUSSION}

The general aims of medical ethics education are translated into practice by the various faculties of medicine in quite diverging ways. In some schools, ethics education is restricted to a few large courses, whereas at the other extreme, ethics education is limited to direct case reports by students. In some of the schools, ethics education is given in a theoretical fashion, while in others the focus is on the practical problems they faced during their training. ${ }^{8}$ This study showed that through conventional lecture with or without an additional small group discussion cognitive level of basic principles of bioethics was decreased, but the level of cognitive achievement and retention for students with an additional small group discussion was higher.

This study used the cognitive developmental approach. This approach was concerned with "the development of logical and critical thinking based on principles as being central and essential to medical education". ${ }^{10}$ Another study reported that small group teaching enabled students to get continuous responses to their argument and ethical position. ${ }^{1}$ The same teaching methods were used in China ${ }^{6}$ and Hongkong ${ }^{12}$ where debates were held frequently on important timely topics in ethics. ${ }^{12}$ Such debates arouse student's interest and offer them further opportunity to apply analytic and problem-solving skills they have learned.

There is, however, less consensus as to what ethics should be taught, how it should be taught and who should teach it. In part, this is because ethics offers not so much discrete or limited area of content, but involves the consideration of values and for dialogue across boundaries and between different perspectives. ${ }^{9}$ Achieving consensus in the focus of medical ethics teaching will be a challenging task. It seems likely that any definition of "medical ethics education", that will be widely acceptable to most medical educators, will have to focus on the ethics of patient care. Ethics is the practice of critical reflection on the principles of right or wrong in human conduct. Ethics focuses on the reasons why an action is considered right or wrong. Ethical deliberation is concerned with the justification for alternative beliefs and actions..$^{10}$

However, various discussion in student groups have shown that even apparent consensus about the principles may hide a difference in interpretation of their central concepts, on the other hand some concepts from other ethical 'schools' such as care ethics, may be just as acceptable as the four principles. ${ }^{8}$

The additional small group discussion in basic principles of bioethics teaching methods in our study used specification checklist method as a strategy to reduce difference in interpretation about basic principles of bioethics. The reason for this was that students could use their capability to assess the ethical principle specification which could enhance student's reasoning analysis of moral justification as guidance for ethical self reflection and ethical practice. ${ }^{10,11}$

In our study, the mean of cognitive retention level of basic principles of bioethics was higher than the adequate cut-off point for the total score even after three months. This result was similar with learning pyramid theory that average learning retention rate from discussion group was about $50 \%{ }^{15}$

There were several limitation of this study that should also be considered. This study only saw ethics in the cognitive developmental approach and did not see the affective developmental approach. Therefore, this study could not show whether there were any changes in student's attitude.

In conclusion, the present study showed that a small group discussion with specification checklist method improved cognitive achievement and retention of basic principles of bioethics.

\section{REFERENCES}

1. Mattick K, Bligh J. Teaching and assessing medical ethics: where are we now? J Med Ethics. 2006;32:181-5

2. Selvakumar D, Joseph LBM. The importance of including bio-medical ethics in the curriculum of health education institutes. Education for Health. 2004;17(1):93-6.

3. Singer PA. Recent advances: medical ethics. BMJ. 2000;321(7256):282-5.

4. Larijani B, Motevasseli EM. Needs and necessities of medical ethics education. DARU. 2006;1 (suppl 1): S21-7.

5. Boyd KM. Medical ethics: principles, persons, and perspectives: from contoversy to conversation. J Med Ethics. 2005;31:481-6.

6. Li B. Ethics teaching in medical school. The Hasting Center Report. 2000;30 (suppl 4):S30-32.

7. Ypinazar VA, Margolis SA. Western medical ethics taught to junior medical students can cross cultural and linguistic boundaries. BMC Medical Ethics. 2004,5:4.

8. Willems D. Ethics education in Medical School. Proceeding of Bilateral Post Graduate Seminar on Ethics; 2005 
December 12-14; Jakarta, Indonesia; Jakarta; FMUI Dutch Foundation: 2005.p.19-22.

9. The Association of Teachers of Ethics and Law in Australian and New Zealand Medical School (ATEAM). An ethics core curriculum for Australasian medical schools. Med J Aust. 2001;175:205-10.

10. Purwadianto A. Medical ethics teaching using principledbased ethics Indonesia experience. Proceeding of Bilateral Post Graduate Seminar on Ethics; 2005 December 12-14; Jakarta, Indonesia. Jakarta; FMUI - Dutch Foundation: 2005.p.8-18.

11. Purwadianto A. Kemampuan mahasiswa baru fakultas kedokteran dalam menilai spesifikasi kaidah dasar bioetika pada Kode Etik Kedokteran Indonesia. Maj Kedokt Indones. 2006;56(11) : p.619-23.
12. Nandi PL, Chan JNF, Chan CPK, Chan P, Chan LPK. Undergraduate medical education: comparison of problembased learning and conventional teaching. Hongkong Med J. 2000;6(3):301-6.

13. Sugito TL, Basuki E, Inge R, Mangindaan L, Purwadianto A, Widiatmaka W, et al. Tutor's guide: Empathy, bioethics, personal and professional development in the context humanities (EBP2DCH) module. Jakarta: Medical Education Unit FMUI, 2007.

14. Afandi D, Budiningsih Y, Safitry O, Purwadianto A, Widjaja IR, Merlina D. Analisis butir uji, reliabilitas dan validitas tes kaidah dasar bioetika. Maj Kedokt Indones. 2008;58(6):205-10.

15. Lalley JP, Miller RH. The learning pyramid: does it point teacher in the rights direction ? Education. 2007; 128(1):64-79. 